Clinical, Radio-Ultrasonographicl and Serological Features of Hydatid and Simple Cysts in Human

\author{
Hiro M. Obaid
}

\title{
Clinical, Radio-Ultrasonographicl and Serological Features of Hydatid and Simple Cysts in Human
}

\author{
Hiro M. Obaid \\ Medical Laboratory Techniques Department- College of Technology- Kirkuk- Foundation of \\ Technical Education- Iraq
}

Received 14 March 2016; Accepted 11 October 2016

\section{$\underline{\text { Abstract }}$}

Intruoduction: Hydatid cyst is remain a health problem of significant concern worldwide. Cystic echinococcosis (CE) is considered to be highly endemic in some countries.

Methods: In this study serological, radiographic and clinical features of simple and hydatid cyst were studied. For this purpose, 114 patients (57 male, 57 femle) whom had clinical or/and radio, ultrasonographic signs for hydatid and simple cysts, were referred to cystic infection in Azadi Teaching Hospital in Kirkuk province, Iraq. The serum samples were examined serologically by ELISA.

Results: Depending on the results of clinical or/and ultrasonographic, a rate of $15.8 \%$ were infected with $\mathrm{CE}$ and a rate of $84.2 \%$ were have simple cysts (SC). While the results of serological examination by ELISA revealed $14.1 \%$ for CE and $85.9 \%$ for SC. The most age group which was significantly infected by CE in males was 56-64 year with a rate of $40 \%$, and the most age group which was significantly infected in females was 65-73 year with rate of $100 \%$.

The CE was significantly more frequent in the liver of infected patients in both males and females, with rates of $71.4,100 \%$ for each gender respectively. The size of most of hydatid cysts were larger than 9 centimeter. People in rural area were most infected than in urban area. 
Clinical, Radio-Ultrasonographicl and Serological Features of Hydatid and Simple Cysts in Human

\section{Hiro M. Obaid}

The frequency of CE were significantly highest among housewife females (43.8\%), and unemployed men $(31.3 \%)$.

Conclusion: CE can be diagnosed and differentiated from SC serologically, even when the cysts are very small and at beginning stage. The radio-ultrasonographic is good in cysts diagnosing but cannot differentiate between types of small sized one.

Key words: Clinical, Serological features, Hydatid cysts, Simple cysts, Human, Kirkuk, Iraq.

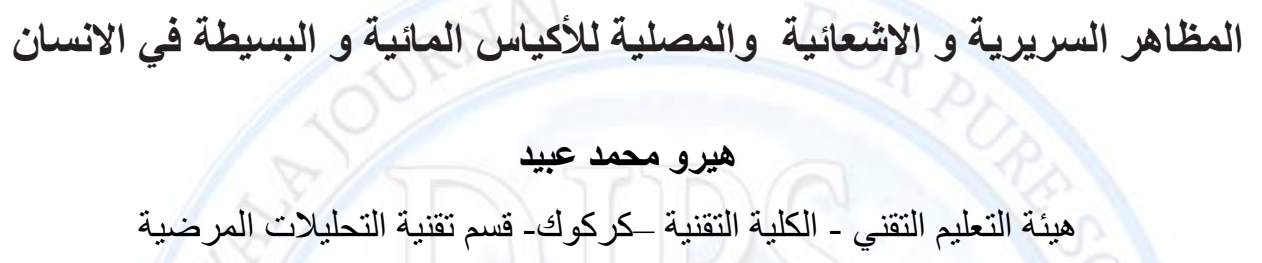

الخلاصة

المقدمة: داء الاكياس المائية لايز ال بشكل مشكلة صحية ذو اهمية معنوية عالمبا، ويكون منتشر بدرجة كبيرة في بعض المناطق و الدول.

طريقة العمل: في هذه الدر اسة المظاهر السريرية المصلية و الصور الصوتية و الاشعائية للاكياس المائية و البسيطة تم دراستها، لهذا الغرض تم اختيار مئة واربعة عشر مريض( 57 انثى و 57 ذكر ) ممن كان لهم نتائج الموجات فوق الصوتية و الاشعاعبة والاعر اض السريرية يدل على اصابتهم بالاكياس البسيطة او المائية. فحص مصول المرضى مناعبا

بطريقة الاليزا.

النتائج: اعتمادا على الاعر اض السريرية والنتائج الاشعائية والموجات فوق الصوتبة، 18 مريض كان موجبا للاكياس المائية وبنسبة 15,8\% و 96 عينة كان للاكياس البسيطة بنسبة 84,2\% ولكن نتائج الدراسة المصلية لم يختلف معنويا واظهر 16 ( 14,1\% ) عينة للاكياس المائية و 98 ( 85,9\% ) عينة للاكياس البسيطة. المرحلة العمرية الاكثر اصابة معنويا في الذكور كان 56-64 سنة بنسبة 40\% بينما المرحلة العمرية الاكثر اصابة في الاناث كانت 65-73 سنة بنسبة 100\%. الاكياس المائية ظهر يتردد اكثر في اكباد المخمين وبنسبة 71,4\% ، 100\% لكل من الذكور و الاناث على التو الي. احجام نسبة عالية من الاكياس المائية كانت اكثر من 9سم. ونسبة الاكياس المائية كانت اعلى معنويا في المناطق الريفية عنه في الحضرية، ظهر الطفيلي بنسبة اكبر في ربات البيوت و الذكور غير الموظفين وبنسبة 43,8 ، 31,3\% لكل فئة على التو الي. 


\section{Clinical, Radio-Ultrasonographicl and Serological Features of Hydatid and} Simple Cysts in Human

\section{Hiro M. Obaid}

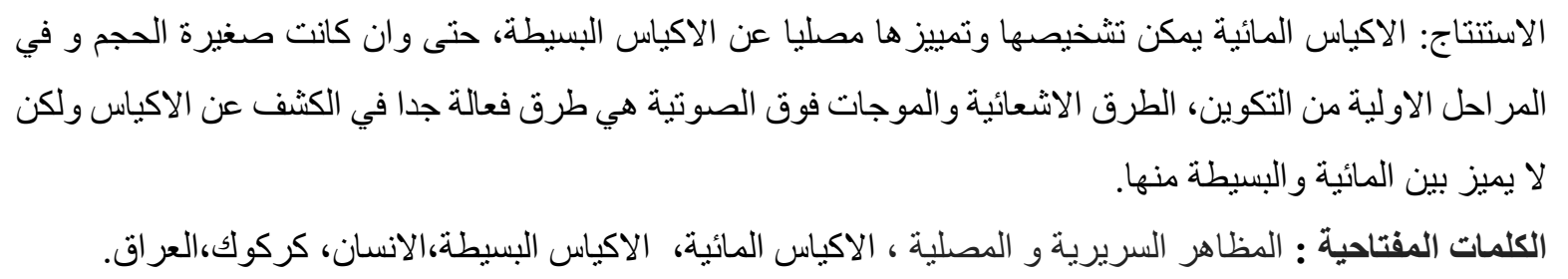

\section{Introduction}

Echinococcosis (Hydatid disease) is an infection caused by the larval instar of cestodes tape worms of the genus Echinococcus, family Taeniidae [1]. Nowadays, four species of Echinococcus are known to infect human (E. granulosus (dog tapeworm), E. multilocularis, E. oligarthrus and E. vogeli). The parasites are continued their life-cycles in carnivores as final hosts and herbivores as intermediate hosts. The egg-producing adult stage is harbored in the intestine of the definitive host, and the metacestode in intermediate host is develops after oral ingestion of the expelled eggs. Metacestodes may also develop in humans causing various forms of echinococcosis [2]. The cyst is diagnosed radiologically, ultrasound and serologic screening are also methods for detection $[3,4,5]$.

Some areas of the world such as Central Europe, the Mediterranean countries, the Middle East, South America, Australia, New Zealand, and South Africa are known to be endemic. It is prevalent sheep-cattle raising regions [6]. Alike with many other parasitic infection, it is tough to summaries data on the occurrence or frequency of CE in humans. In Iraq as in other area the CE is endemic, in Arbil province in northern Iraq, 99 cases were documented between 1990 and 1998 resulting in an yearly average of 12.4 cases and an expected occurrence of 2 cases per 100,000 [7]. In Kirkuk and Tikrit cities, from 2000 to 2003, a 125-hydatid cyst cases were recorded, 82 in Kirkuk and 43 in Tikrit [5]. In Baghdad in 2006, 94 patients were diagnosed for hydatid cyst, 20 of them were urgent [8]. In Hilla also 61patients were recorded to have CE in 2011-2012 [9]. Of all general surgeries in Saudi Arabia 0.3\% of them were accounts CE, the prevalence is estimated to be 1.6-3.6 cases per 100,000 population in Kuwait, E. granulosus had apparently low prevalence in Oman animals and humans due to their unusual 
Clinical, Radio-Ultrasonographicl and Serological Features of Hydatid and Simple Cysts in Human

\section{Hiro M. Obaid}

epidemiological conditions [10]. In the entire Iran more than 5,000 patients of CE were treated surgically in a 14-year period (1980-1993) [11]. A 676 CE surgical cases in Jordan have been recorded between 1985 and 1993, and the annual rates in different areas of the country were valuated to be 0.5 to 8.2 cases per 100,000 [12]. Recent records accentuate that CE continues to be public health problem in humans in Morocco, Algeria, Tunisia and Libya and seemingly to a smaller degree in Egypt where the yearly frequency of hospital cases is expected to be less than 1 per 100,000 population [13]. Since the increase of emigration and trade, the hydatid cyst can befall also in non-widespread countries [6].

Simple cysts are comparatively more common. The simple cyst histopathologically characterized by wall composed of a thin layer of epithelial cells and having serous fluid on sonography. Hydatid cysts are generally asymptomatic and discovered accidentally on sonography. The appearance of hydatid cysts on sonography is inconstant and hinge on the stage of maturity and the diagnostic accuracy of sonography is required for cysts with a noticeable cyst wall [14]. The hydatid cyst is a fluid-filled cavity, consisting of an outside thick host formed fibrous wall and two inner parasite-derived layers, which is an external laminated and internal germinal layer[2]. The ordinary investigative methodology for cystic echinococcosis comprises imaging techniques, mainly ultrasonography, computed tomography (CT), X-ray examinations, and by detection of specific serum antibodies by immunodiagnostic tests. Enzyme linked immunosorbent assay (ELISA) test using hydatid cyst fluid has a high sensitivity (>95\%) [4].

Because there is very little studies on CE in Kirkuk city and the necessity of distinguishing the CE from SC especially at the first steps of formation, the aim of the present study was to detect and differentiate the CE from SC sonographically, radiograhpically, serologically and by clinical features in patients of Kirkuk province. 
Clinical, Radio-Ultrasonographicl and Serological Features of Hydatid and Simple Cysts in Human

\section{Hiro M. Obaid}

\section{Materials and Methods}

\section{1-Population Study:}

From January to November of the year 2014, a total 114 patients were eligible for seroscreening for hydtid cyst, according to the examination of the physician, and the clinical signs which referred to cystic infection. Data's including gender, age, location of cyst, size of cyst, type of cyst, residential areas and occupation of all patients were recorded. The patients were referred to Azadi Teaching Hospital in Kirkuk province, Iraq. The ultrasound, x-rays diagnosis of the patients was discussed with the physician.

\section{2-Serum samples collection:}

2-3 $\mathrm{ml}$ of venous blood was drained cautiously and transferred into disposable plan tube, the specimen was left for (15-30) then centrifuged at $300 \mathrm{rpm}$ for (5min) to isolate clear serum, sera were kept at $\left(-20^{\circ} \mathrm{C}\right)$ till they were assayed by ELISA [4]. (Blood was taken from the patients after they had finished the x-rays or sonography tests).

\section{3-ELISA (Enzyme Linked Immunosorbent Assay) kit:}

For determining the presences of specific human E. granulosus $\operatorname{IgE}$ (allergenic protein). ELISA kit was used instructed procedure of the BIO RAD (Bio-Rad Laboratories.3Brd R. France).

Principle of the assay: The qualitative immunoenzymatic determination of IgG class antibody against Echinococcus is based on the ELISA technique. Micro titer strip wells are pre coated with Echinococcus antigen to bind corresponding antibodies of the specimen. After washing the well to remove all unbound sample material horseradish peroxidase (HRP) labeled antihuman IgG conjugate is added. Then this conjugate binds to the capture Echinococcus-specific antibodies. The immune complex formed by the bound conjugate is visualized by adding Tetramethylbenzidine-(TMB) substrate which gives a blue reaction product. The intensity of this product is proportional to the amount of Echinococcus-specific IgG antibodies in the specimen. Sulphuric acid is added to stop the reaction. This produces a yellow end point color. Absorbance at $450 \mathrm{~nm}$ is read using an ELISA microwell plate reader. 
Clinical, Radio-Ultrasonographicl and Serological Features of Hydatid and Simple Cysts in Human

\section{Hiro M. Obaid}

\section{4-Statistical Analysis:}

$\chi^{2}$ (chi-square) test in style of independent and in style of homogeneous were used manually. The significant level used was $\mathrm{P}<0.05$.

\section{$\underline{\text { Results }}$}

This study had included the prevalence of hydatid and simple cyst population of Kirkuk city which was detected by sonography, radiography and serologically. The result (Table1) showed no significant differences $(\mathrm{p}<0.05)$ between sono-radiography and serology methods in CE diagnosing. The frequency rate of $\mathrm{CE}$ was $14.1,15.8 \%$ for each of serology and sonoradiography methods respectively .

Table 1. Prevalence of hydatid and simple cysts

\begin{tabular}{|c|c|c|c|c|c|c|c|c|c|}
\hline \multirow{3}{*}{ Gender } & \multirow{3}{*}{ Patient } & \multicolumn{4}{|c|}{ Serology (ELISA) } & \multicolumn{4}{|c|}{ Sono-radiography } \\
\hline & & \multicolumn{2}{|c|}{ Simple } & \multicolumn{2}{|c|}{ Hydatid } & \multicolumn{2}{|c|}{ Simple } & \multicolumn{2}{|c|}{ Hydatid } \\
\hline & & cyst & $\%$ & Cyst & $\%$ & cys & $\%$ & Cyst & $\%$ \\
\hline Male & 57 & 50 & 87.7 & 7 & 12.3 & 50 & 87.7 & 7 & 12.3 \\
\hline Female & 57 & 48 & 84.2 & 9 & 15.8 & 46 & 80.7 & 11 & 19.3 \\
\hline Total & 114 & 98 & 85.9 & 16 & 14.1 & 96 & 84.2 & 18 & 15.8 \\
\hline$\chi^{2}$ value & Evaluated & & & & & & & & \\
\hline
\end{tabular}

The result in table 2 indicated that there were no significant differences in CE infection between male and female $(\mathrm{P}>0.05)$, but significant difference were appeared between age groups in both males and females. The most age group which were infected with the CE in male was 5664 year with rate of $40 \%$, followed by $20-28$ with rate $18.2 \%$, no positive sample were detected in each of 11-19, 47-55, 65-73 age group. In female the highest rate (100\%) of infection was in 
Clinical, Radio-Ultrasonographicl and Serological Features of Hydatid and Simple Cysts in Human

\section{Hiro M. Obaid}

65-73 year, followed 29-37 year with rate of $16.7 \%$, the lowest rate $(0 \%)$ was in 20-28 years old.

Table 2. Seroprevalence of hydatid cyst according to age and sex

\begin{tabular}{|c|c|c|c|c|c|c|c|c|c|c|}
\hline Sex & \multicolumn{5}{|c|}{ Male } & \multicolumn{5}{|c|}{ Female } \\
\hline $\begin{array}{l}\text { Age } \\
\text { group } \\
\text { in } \\
\text { years }\end{array}$ & $\begin{array}{l}\text { Examined } \\
\text { numbers }\end{array}$ & $+\mathrm{ve}$ & $\%$ & ve & $\%$ & $\begin{array}{c}\text { Examined } \\
\text { numbers }\end{array}$ & $+v e$ & $\%$ & ve & $\%$ \\
\hline $2-10$ & 6 & 1 & 16.7 & 5 & 83.3 & 4 & 1 & 25 & 3 & 75 \\
\hline $11-19$ & 9 & 0 & 0 & 9 & 100 & 7 & 1 & 14.3 & 6 & 85.7 \\
\hline $20-28$ & 11 & 2 & 18.2 & 9 & 81.8 & 12 & 0 & 0 & 12 & 100 \\
\hline $29-37$ & 10 & 1 & 10 & 9 & 90 & 12 & 2 & 16.7 & 10 & 83.3 \\
\hline $38-46$ & 6 & 1 & 16.7 & 5 & 83.3 & 9 & 1 & 11.1 & 8 & 88.9 \\
\hline $47-55$ & 7 & 0 & 0 & 7 & 100 & 7 & 1 & 14.3 & 6 & 85.7 \\
\hline $56-64$ & 5 & 2 & 40 & 3 & 60 & 4 & 1 & 25 & 3 & 75 \\
\hline $65-73$ & 3 & 0 & 0 & 3 & 100 & 2 & 2 & 100 & 0 & 0 \\
\hline Total & 57 & 7 & 12.3 & 50 & 87.7 & 57 & 9 & 15.8 & 48 & 84.2 \\
\hline $\begin{array}{c}\chi^{2} \\
\text { value }\end{array}$ & \multicolumn{5}{|c|}{$\begin{array}{c}\text { Evaluated } \chi^{2} \text { value }=16.4, \chi^{2} \\
\text { value of } \mathrm{P}<0.05=14.1 \\
\text { ( } \text { significant) }\end{array}$} & \multicolumn{5}{|c|}{$\begin{array}{c}\text { Evaluated } \chi^{2} \text { value }=14.4, \chi^{2} \\
\text { value of } \mathrm{P}<0.05=14.1 \\
\text { (significant) }\end{array}$} \\
\hline
\end{tabular}

The occurrence of hydatid cysts in varies sites of the patients organs confirmed by ELISA are illustrate in table 3,4 . The result was significant for both male and female. The most organ which was infected with hydatid cyst in male was the liver with the maximum infection rate of $71.4 \%$. The second highest rate of infection was in the lung with rate of $100 \%$ followed by back with a rate of $14.3 \%$. The maximum infection number was 5 with rate of $100 \%$ for liver in female, and the lung, brain, kidney, gallbladder all was with the same infection rate (Table 4). 
Clinical, Radio-Ultrasonographicl and Serological Features of Hydatid and Simple Cysts in Human

\section{Hiro M. Obaid}

Table 3. Distribution of simple and hydatid cyst among different organs in males.

\begin{tabular}{|c|c|c|c|c|c|}
\hline $\begin{array}{c}\text { Cyst } \\
\text { location }\end{array}$ & $\begin{array}{c}\text { Total cyst } \\
\text { No. }\end{array}$ & $\begin{array}{c}\text { Simple } \\
\text { cyst }\end{array}$ & $\%$ & $\begin{array}{c}\text { Hydatid } \\
\text { cyst }\end{array}$ & $\%$ \\
\hline Face & 7 & 7 & 100 & 0 & 0 \\
\hline Head & 10 & 10 & 100 & 0 & 0 \\
\hline Hand & 13 & 13 & 100 & 0 & 0 \\
\hline Foot & 4 & 4 & 100 & 0 & 0 \\
\hline Back & 7 & 6 & 85.7 & 1 & 14.3 \\
\hline Neck & 7 & 7 & 100 & 0 & 0 \\
\hline Liver & 7 & 2 & 28.6 & 5 & 71.4 \\
\hline Gallbladder & 1 & 1 & 100 & 0 & 0 \\
\hline Lung & 1 & 0 & 0 & 1 & 100 \\
\hline Total & 57 & 50 & 87.7 & 7 & 12.3 \\
\hline$\chi^{2}$ value & Evaluated $\chi^{2}$ value $=36.09, \chi^{2}$ value of $\mathrm{P}<0.05=26.3($ \\
\hline
\end{tabular}

Table 4. Distribution of simple and hydatid cyst among different organs in females.

\begin{tabular}{|c|c|c|c|c|c|}
\hline $\begin{array}{c}\text { Cyst } \\
\text { location }\end{array}$ & Total cyst No. & $\begin{array}{c}\text { Simple } \\
\text { cyst }\end{array}$ & $\%$ & $\begin{array}{c}\text { Hydatid } \\
\text { cyst }\end{array}$ & $\%$ \\
\hline Face & 6 & 6 & 100 & 0 & 0 \\
\hline Head & 7 & 7 & 100 & 0 & 0 \\
\hline Hand & 12 & 12 & 100 & 0 & 0 \\
\hline Foot & 2 & 2 & 100 & 0 & 0 \\
\hline Back & 3 & 3 & 100 & 0 & 0 \\
\hline Ovary & 12 & 12 & 100 & 0 & 0 \\
\hline Neck & 6 & 6 & 100 & 0 & 0 \\
\hline Liver & 5 & 0 & 0 & 5 & 100 \\
\hline Brain & 1 & 0 & 0 & 1 & 100 \\
\hline Lung & 1 & 0 & 0 & 1 & 100 \\
\hline Kidney & 1 & 0 & 0 & 1 & 100 \\
\hline Gallbladder & 1 & 0 & 0 & 1 & 100 \\
\hline Total & 57 & 48 & 84.2 & 9 & 15.8 \\
\hline$\chi^{2}$ value & Evaluated $\chi^{2}$ value $=58.44, \chi^{2}$ value of $\mathrm{P}<0.05=36.4($ \\
\hline \multicolumn{5}{|l|}{ significant $)$} \\
\hline
\end{tabular}


Clinical, Radio-Ultrasonographicl and Serological Features of Hydatid and Simple Cysts in Human

\section{Hiro M. Obaid}

The relationship of CE with the residential area is illustrated in table 5. The result showed that the most significant residential area which was infected by hydatid cyst was in Chamchamal, Hawija, Tuz with rates of 66.7, 42.9, 50\% respectively for each area. krfri, Failak, Daquq had same rate $(33.3 \%)$ of infection. While in the city center the infection with the hydatid cyst in the Wasti, 1 Huzairan, Qadisiyah, Shroija were with rates of 20,16.7, 14.3, 13.3\% respectively for each area.

Table 5. Distribution of simple and hydatid cysts according to patient's residence

\begin{tabular}{|c|c|c|c|c|c|}
\hline $\begin{array}{c}\text { Residential } \\
\text { area }\end{array}$ & Total cyst No. & $\begin{array}{c}\text { Simple } \\
\text { cyst }\end{array}$ & $\%$ & $\begin{array}{c}\text { Hydatid } \\
\text { cyst }\end{array}$ & $\%$ \\
\hline Wasti & 10 & 8 & 80 & 2 & 20 \\
\hline Raheem awa & 15 & 15 & 100 & 0 & 0 \\
\hline 1 huzairan & 6 & 5 & 83.3 & 1 & 16.7 \\
\hline Imam qasim & 2 & 2 & 100 & 0 & 0 \\
\hline Panja ali & 6 & 6 & 100 & 0 & 0 \\
\hline Shorijh & 15 & 13 & 86.7 & 2 & 13.3 \\
\hline Al-huria & 9 & 9 & 100 & 0 & 0 \\
\hline Tariq bagdad & 6 & 6 & 100 & 0 & 0 \\
\hline Hai al-askari & 12 & 12 & 100 & 0 & 0 \\
\hline Tuz & 4 & 3 & 100 & 0 & 0 \\
\hline Dbbs & 3 & 2 & 66.7 & 1 & 33.3 \\
\hline Kefri & 3 & 1 & 33.3 & 2 & 66.7 \\
\hline Chamchamal & 3 & 2 & 66.7 & 1 & 33.3 \\
\hline Failak & 3 & 4 & 57.1 & 3 & 42.9 \\
\hline Hawija & 7 & 2 & 66.7 & 1 & 33.3 \\
\hline Daquq & 3 & 6 & 85.7 & 1 & 14.3 \\
\hline Qadisiyah & 7 & 98 & 85.9 & 16 & 14.1 \\
\hline Total & 114 & $($ significant $)$ & & \\
\hline$\chi^{2}$ value & Evaluated $\chi^{2}$ value $=27.96, \chi^{2}$ value of $\mathrm{P}<0.05=26.3$ \\
\hline & & & & \\
\hline
\end{tabular}

The main presenting symptoms in CE infected individuals (Fig.1) were jaundice with rate of $74 \%$ followed by right upper quarter (RUQ) pain with rate of $62.5 \%$. The less symptoms appeared were hematuria and intracranial pressure having the same rate $(6.3 \%)$. 
Clinical, Radio-Ultrasonographicl and Serological Features of Hydatid and Simple Cysts in Human

\section{Hiro M. Obaid}

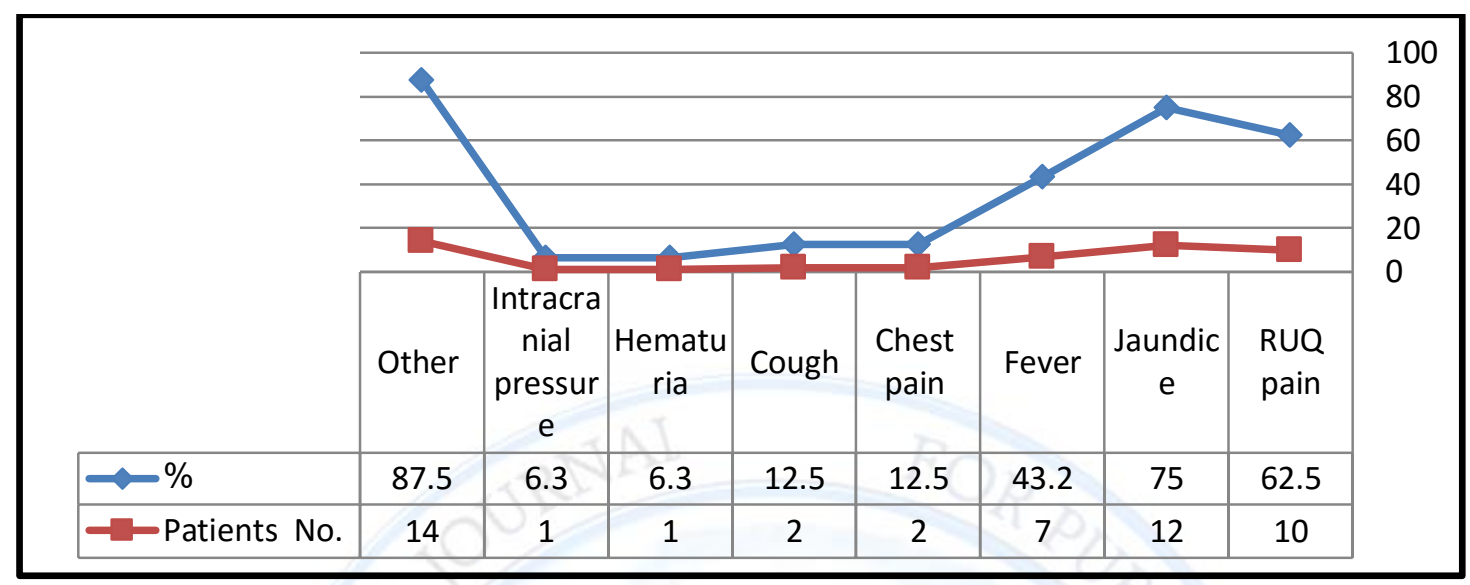

Figure 1. Cystic echinococcosis symptoms

Regarding the occupation of the patients significant difference was appeared between them (table 6). The significantly highest incidence of the disease in females were among housewives with rate of $100 \%$ while in men were among unemployed with rate of $100 \%$. The incidence of the hydatid cyst in the students were $18.8 \%$.

Table 6. Distribution of hydatid cysts in relation to patient's occupation.

\begin{tabular}{|c|cc|c|c|c|c|}
\hline Occupation & \multicolumn{2}{|c|}{ Total cyst No. \% } & Male & $\%$ & Female & $\%$ \\
\hline Housewives & 7 & 43.8 & 0 & 0 & 7 & 100 \\
\hline $\begin{array}{c}\text { Unemployed } \\
\text { men }\end{array}$ & 5 & 31.3 & 5 & 100 & 0 & 0 \\
\hline Student & 3 & 18.8 & 2 & 66.7 & 1 & 33.3 \\
\hline Child & 1 & 6.3 & 0 & 0 & 1 & 100 \\
\hline Total & 16 & 100 & 7 & 43.7 & 9 & 56.3 \\
\hline$\chi^{2}$ value & \multicolumn{7}{|c|}{ Evaluated $\chi^{2}$ value $=14.72, \chi^{2}$ value of $\mathrm{P}<0.05=7.81$} \\
(significant)
\end{tabular}

The size of the cysts detected were significantly different between the simple and hydatid cyst (table 7). The smaller sizes were for simple cyst and the bigger were for hydatid cyst. Most of 
Clinical, Radio-Ultrasonographicl and Serological Features of Hydatid and Simple Cysts in Human

\section{Hiro M. Obaid}

the hydatit cyst detected were between $9-11 \mathrm{~cm}$. and bigger size with rate of $100 \%$. Low percent of hydatid cyst had small size $(3-5 \mathrm{~cm})$ with rate of $3.3 \%$.

Table 7. Distribution of simple and hydatid cyst by size.

\begin{tabular}{|c|c|c|c|c|c|}
\hline $\begin{array}{c}\text { Size of } \\
\text { cyst in cm. }\end{array}$ & Total cyst No. & Simple cyst & $\%$ & $\begin{array}{c}\text { Hydatid } \\
\text { cyst }\end{array}$ & $\%$ \\
\hline$<3$ & 53 & 53 & 100 & 0 & 0 \\
\hline $3-5$ & 30 & 29 & 96.7 & 1 & 3.3 \\
\hline $6-8$ & 19 & 16 & 84.2 & 3 & 15.4 \\
\hline $9-11$ & 8 & 0 & 0 & 8 & 100 \\
\hline $11>$ & 4 & 0 & 0 & 4 & 100 \\
\hline Total & 114 & 98 & 85.9 & 16 & 14.1 \\
\hline$\chi^{2}$ value & Evaluated $\chi^{2}$ value $=85.2, \chi^{2}$ value of $\mathrm{P}<0.05=15.5$ \\
(significant) \\
\hline
\end{tabular}

Figure 2 shows the type of simple cysts detected. The most high frequency of simple cyst were for sebaceous cysts which represented by 59 cysts with rate of $60.2 \%$, while the lower frequency were for natal cysts which represented by 5 cysts with rate of $5.1 \%$.

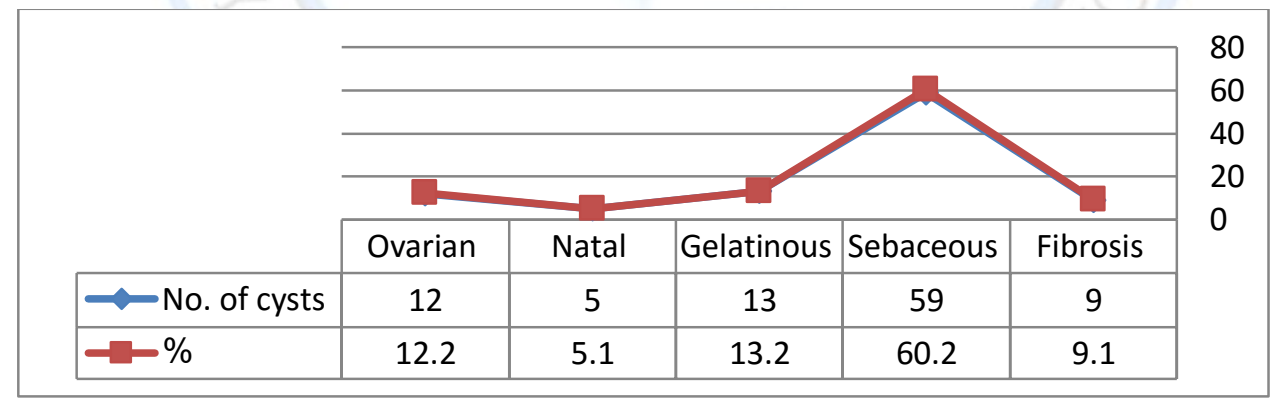

Figure 2. Type of simple cysts.

Comparative diagnosis of hydatid cyst by examination of both ultra sound (US), radiography (RA) and serology by ELISA (Fig.3), revealed 16 positive sample by ELISA while the US-RA were diagnosed 18 sample. Figure $(4,5)$ shows simple and hydatid cyst diagnosed by US. The 


\section{DIYGLA JOURNAL FOR PURE SCIENCES}

Clinical, Radio-Ultrasonographicl and Serological Features of Hydatid and Simple Cysts in Human

\section{Hiro M. Obaid}

simple cysts wall is not visible on sonography and its look like ghost (Fig. 4), while the diagnostic accuracy of sonography is high for hydatid cysts with a visible cyst wall (Fig.5).

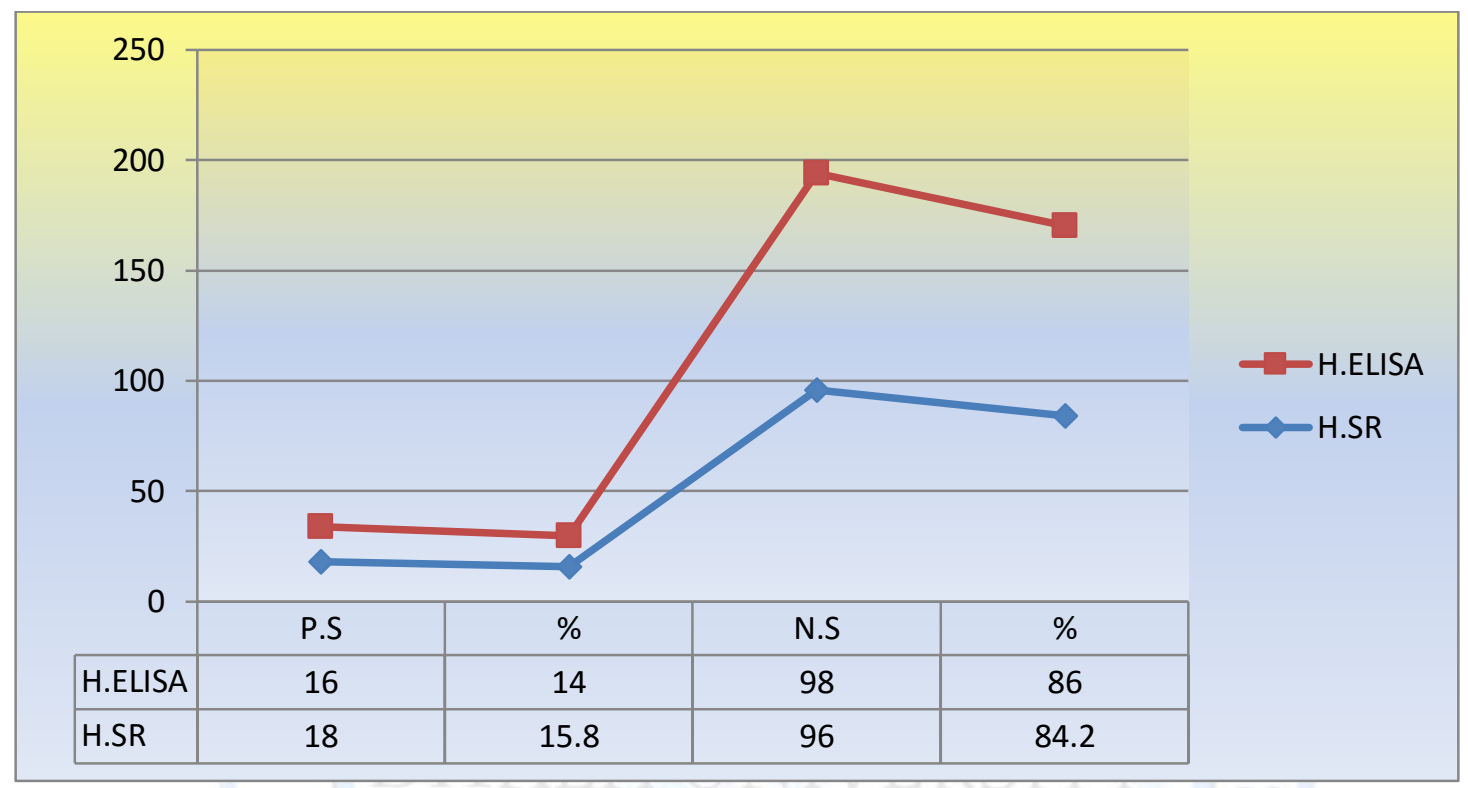

Figure 3. Comparison of ultra sound and ELISA in hydatid cyst detection. $(\mathrm{H}=$ hydatid cyst, $\mathrm{P}=$ positive, $\mathrm{N}=$ negative, $\mathrm{S}=$ =sample, $\mathrm{SR}=$ sono-radiography )

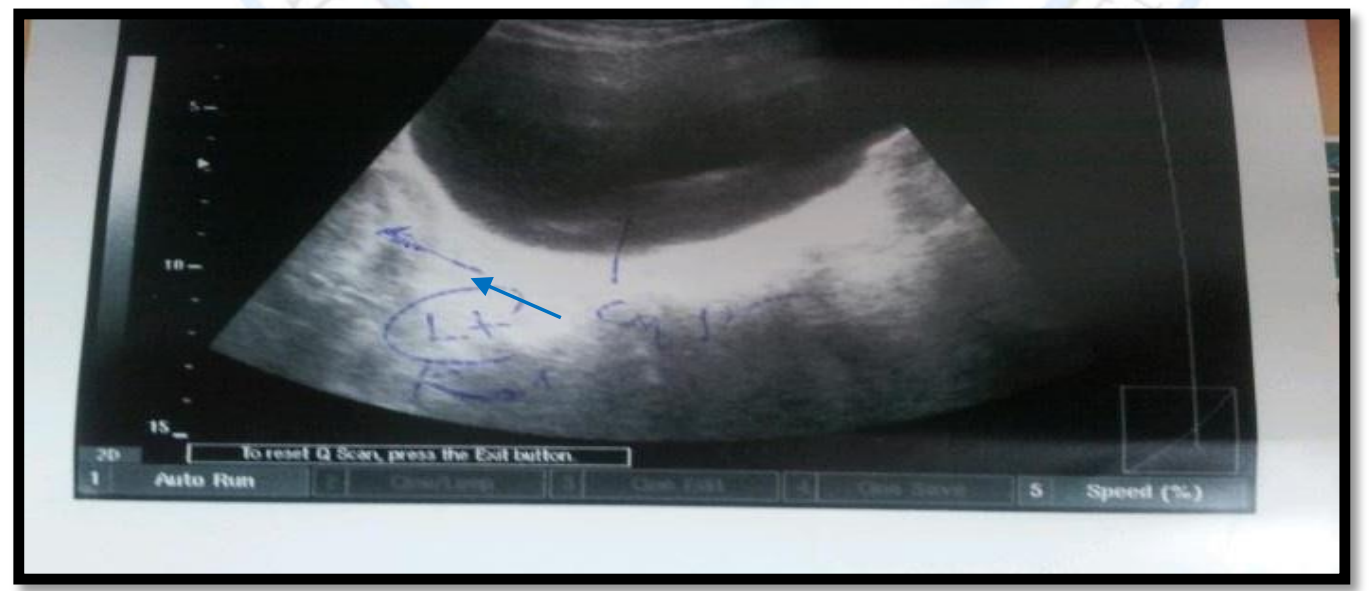

Figure 4. Simple cyst appearance by ultra sound (blue arrow ahead) 
Clinical, Radio-Ultrasonographicl and Serological Features of Hydatid and Simple Cysts in Human

\section{Hiro M. Obaid}

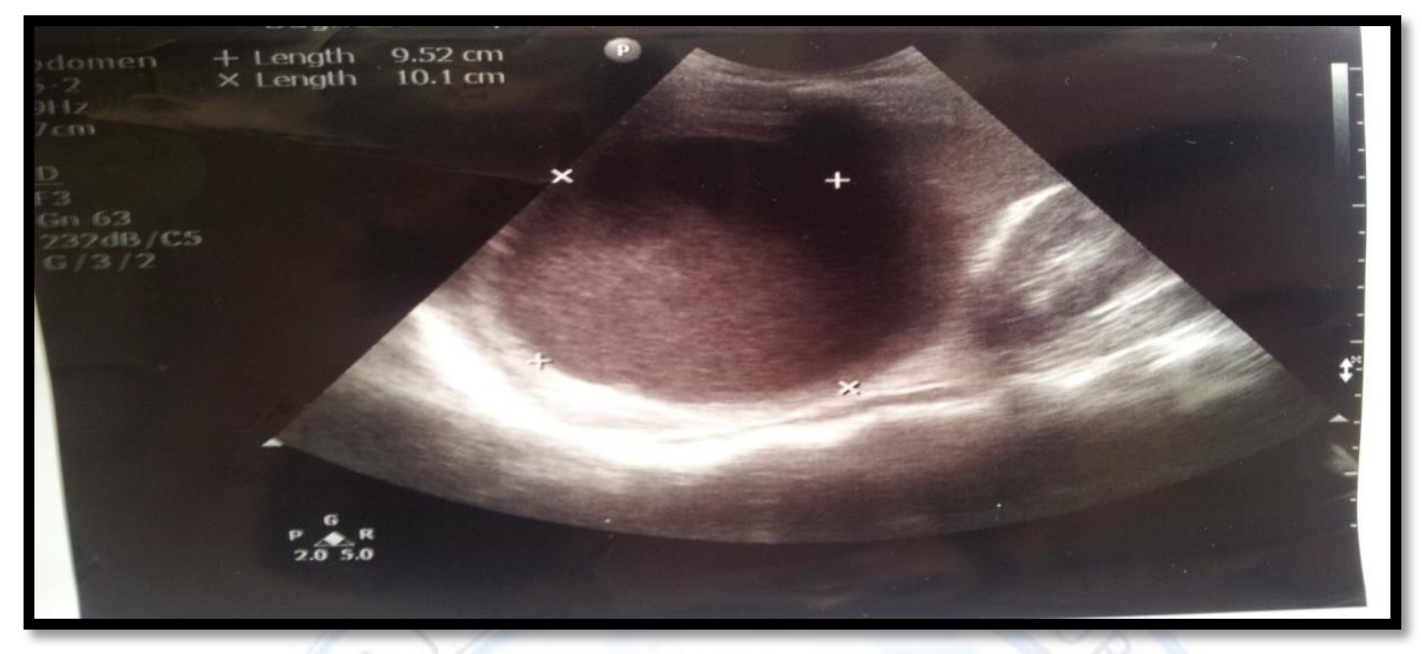

Figure 5. Hydatid cyst appearance by ultra sound (crosses refer to cystic wall layer).

\section{$\underline{\text { Discussion }}$}

Hydatidosis is remain a main public health problem in our country as in some other parts of the realm [8]. The adult worm is attached to the small intestinal of animals like dog, fox, wolf, cat and millions eggs are dispersed with each animal defecation [2].

As far as we know the age distribution is apprehensive, the present study appeared the highest surgical prevalence in the 56-64 years in male. Namely, that the maximum age of the incidence was the fifth decade which agreed with [5]. In contrast, apparently conflicted with that recorded by others $[15,5]$. High incidence occurred in age between 30-60 years in women [16], was similar to our study result.

In most endemic areas as known, a sizeable amounts of the entire inhabitants at risk are small ages, in contrary the disease mostly affect grown persons at the labor age, high number of hydatid cyst infections are certainly acquired in the period of the childhood but needs several years to patent themselves as harmful lesions. In this study as in usual in hydatid infection, the liver in both sexes was more frequently site involved than in other organs. However, the lung is being the next. These findings are in agreement with results of other studies $[5,16,17]$. In contrast, that some of studies recorded the predominance of the lung hydatid cysts infection 


\section{Clinical, Radio-Ultrasonographicl and Serological Features of Hydatid and} Simple Cysts in Human

\section{Hiro M. Obaid}

over the hepatic involvement $[18,19]$. It is well known that liver is most frequently affected, that is interpreted to the fact that the liver acts as primary filter in the human body. However, conspicuously, the exact mechanism for the hydatid cysts development sites are yet not clear [20]. The main presenting symptoms showed in this study was jaundice, RUQ (right upper quadrant) pain and fever which agreement with other studies $[8,9,16]$.

This study indicated that the rate of hydatid cyst in female is significantly higher than in male, or nearly equal in two sexes, confirming the findings of others $[8,9,21]$, perhaps this because the females are more commonly involved in dealing with meat, contaminated food and vegetables, and with animals $[9,22]$. In spite of this, investigational studies showed that the males were more prone to contract the disease than the females [23]. In the present study the majority of hydatid cysts cases were among the housewives, this is in agreement with that found by several other studies $[5,15,17]$.

However, high incidence of the disease among housewives may be due to their extreme domesticity in a habitat and handy connotation with infected dogs. Concerning the residence, most of the study cases were from the rural areas (66.7\%), This is agreement to other study done in Iraq, in whom they found higher rates $(82 \%, 62.9)$ in rural areas respectively $[9,15]$ . In this study it was noticed that the majority size of cysts diameters between 9-11 which is agreement with that found by other researchers they recorded high frequency in bigger cyst size ( more than $10 \mathrm{~cm}$, mean of $11.4 \mathrm{~cm}$ ) [8,16]. This is because the symptoms depending on size of cyst and this disease at beginning of infection is asymptomatic until the cyst become large in size then appear of symptoms so then patient feeling there is a problem.

Among simple cysts, sebaceous cyst appeared to be the most common with rate of (51.8\%) this in agreement with other studies $[24,25,26]$ because they may occur anywhere on the body except in areas where no hair, like hand palms.

The diagnosis of hydatid cyst is usually made by typical sonographic features. The sonography appearance of hydatid cysts is variable and hinge on on the phase of maturity [2]. 25-40\% of completely liquid type hydatid cysts appear as well-defined anechoic cysts with no wall structure and thus are sonographically indistinguishable from simple cysts [14] Likewise, on 


\section{Clinical, Radio-Ultrasonographicl and Serological Features of Hydatid and} Simple Cysts in Human

\section{Hiro M. Obaid}

MRI the distinguishing morphologic features of cystic echinococcosis types 1, 2, and 3 hydatid cysts are supportive in the differential diagnosis, whereas completely liquid hydatid cysts are indistinguishable from simple cysts [3]. In present study the serologically result had not differed from that of sonography making both of them good tool for diagnosing this is somehow agree with that found by [2] whom revealed sonography to be good tool in CE diagnosing, and with [5] whom revealed serology method ( ELISA ) to be more sensitive than LATEX in CE diagnosing but The conclusion of our study is that: CE can be diagnosed and differentiated from SC serologically, even when the cysts are very small and at beginning stage. The radioultrasonographic is good in cysts diagnosing but cannot differentiate between types of small sized one.

\section{$\underline{\text { References }}$}

1. Thompson RC, McManus DP. : Towards a taxonomic revision of the genus Echinococcus. Trends Parasitol. 2002;18:452-7.

2. Khanfar N. :Hydatid disease: a review and update. Current An aesthesia \& Critical Care $.2004 ; 15,173-183$.

3. Biava MF. Dao A., Fortier B.: Laboratory Diagnosis of Cystic Hydatid disease. World J Surg. 2001; 25:10-14.

4. Ramtin H, Fatemeh M \&Mohammad B R. :Evaluation of A dot-ELISA for the serodignosis of human hydatiad disease, Pak.J. Med .Sci. 2003. 19(4) 268-271.

5. Kadir MA, Adil S, Samsh AL-Den S. :Seropidemiology of human hydatidosis in Kirkuk and Tikrit/ Iraq .J. Fac Med Baghdad. 2006.48(4) 397-401.

6. Berger SA, Marr JS. :Human parasitic diseases sourcebook. Jones and Bartlett Publishers: Sudbury, Massachusetts, 2006.

7. Saeed I, Kapel C, Saida LA, Willingham L. \& Nansen P. :Epidemiology of Echinococcus granulosus in Arbil province, northern Iraq, 1990-1998. J. Helminthol., 2000. 74, 83-88.

8. Sarhan HH, :Urgent surgery in hydatid cyst disease. Tikrit Medical Journal 2008; 14 (1):99-105. 
Clinical, Radio-Ultrasonographicl and Serological Features of Hydatid and Simple Cysts in Human

\section{Hiro M. Obaid}

9. Al-Yasari HF and Al-Shaiely AK. :A study of human hydatidosis: demographically and clinically in Hilla city. J. Babylon Univ./Pure and Applied Scie. 20138 (21): 2873-2882.

10. Dar FK \& Alkarmi T. :Cystic echinococcosis in the Gulf Littoral States. In Compendium on cystic echinococcosis in Africa and in Middle Eastern Countries with special reference to Morocco (F.L. Andersen, H. Ouhelli \& M. Kachani, eds). Brigham Young University, Print Services, Provo, Utah, 1997. 281-291.

11. Ataeian A \& Nourian A. :Hydatidosis and echinococcosis in Iran. Arch. int. Hidatid., 1997. $32,239-240$.

12. Kamhawi S. :A retrospective study of human cystic echinococcosis in Jordan. Ann. trop. Med. Parasitol., 1995. 89, 409-414.

13. Shambesh MK. :Human cystic echinococcosis in North Africa (excluding Morocco). In Compendium on cystic echinococcosis in Africa and in Middle Eastern Countries with special reference to Morocco (F.L. Andersen, H. Ouhelli \& M. Kachani, eds). Brigham Young University, Print Services, Provo, Utah, 1997. 223-244.

14. Mortelé KJ, Ros PR. :Cystic focal liver lesions in the adult: differential CT and MR imaging features. RadioGraphics. 2001.Young. Brucella species. In: Mandell, Douglos, Bennett, editors. Principles and practice of infectious disease, 6th edition. Pensylvania: Churchill livingstone; 2005.

15. Al-Obaidi HS, Salman AA, Arziak Z. :Epidemiology of hydatid cyst with experimental trial of the anti-parasitic activity of ivermectin in compare to other common antiparasitic drug. Tikrit Medical Journal .2008. 14(1): 1-11

16. Al-aubaidi T. :Surgical treatment of hydatid cyst of the liver. Iraqi postgraduate medical journal. 2010.9 (2):189-195.

17. Saida LA and Nouraddin AS.: Epidemiological study of cystic echinococcosis in Man and slaughtered animals in Erbil province, Kurdistan Regional-Iraq. Tikrit Journal of Pure Science. 2011. 16 (4) :45-50.

18. Setareh M, Setareh S, Babak P. :Hydatid disease in Iranian children. Pediatric hydatidosis in Iran. 2011.40:428-431 
Clinical, Radio-Ultrasonographicl and Serological Features of Hydatid and Simple Cysts in Human

\section{Hiro M. Obaid}

19. Benyan Z and Mahdi K. :Pulmonary Hydatidosis in Man and his Livestock in Southern Iraq. Saudi Medical Journal. 2011. 8 (4): 402-406.

20. .Eckert J and Deplaze P. :Clinical Microbiology Reviews: Biological, epidemiological, and clinical aspects of Echinococcosis, a Zoonosis of increasing concern. 2004; 17: 107 - 135.

21. Mahdi K and Benyan Z. :Hydatidosis among Iraqi Children. Annals of Tropical Medicine and Parasitology, 1990: 84.2-11.

22. Zeki AA, Mazin HA, Wadah M. :Complicated Hydatid cyst In Basra, Iraqi journal of gastroerterology.2002,1(2):27-31.

23. Frayh J, Lawelor K, Dajani M. :Echinococcus Granulosus in Albino Mice; Effect of Host Sex and Sex Hormones on the Growth of HC. Exp. Parasit. 1971:29; 255 - 262.

24. Eknoyan G. :A clinical view of simple and complex renal cysts. J Am Soc Nephrol . 2009; 20: $1874-6$.

25. Gaines PA, Sampson MA. :The prevalence and characterization of simple hepatic cysts by ultrasound examination. Br J Radiol. 1989; 62: 335-7.

26. Ashby KL. : "Ovarian Cyst". In Loue, Sana \& Sajatovic, Martha. Encyclopedia of Women's Health. Springer. 2004, p. 476. 